\title{
Regeneration of insulin production by autologous bone marrow blood autotransplantation in patients with type 1 diabetes
}

\author{
E. Esmatjes • X. Montaña $\cdot$ M. I. Real • J. Blanco • \\ I. Conget $\cdot$ R. Casamitjana $\cdot$ M. Rovira $\cdot$ R. Gomis • \\ P. Marin
}

Received: 20 November 2009 /Accepted: 11 December 2009/Published online: 26 January 2010

(C) Springer-Verlag 2010

Keywords Autotransplantation - Beta cell function ·

Bone marrow · Type 1 diabetes

To the Editor: Among the possible cellular therapies to replace insulin secretion in diabetes, bone marrow-derived stem cells have aroused interest because of their plasticity and ease of procurement. Indeed, some experimental reports suggest that the bone marrow harbours cells capable of differentiation into beta cells [1-3], the transplantation of which can correct hyperglycaemia [1, 4]. However, these findings have not been corroborated in other studies [5]. Nonetheless, the experimental data are not conclusive and point to three potential roles of bone marrow cells in the treatment of diabetes, namely as a source of stem cells for

Trial registration: ClinicalTrials.gov NCT00821899

E. Esmatjes $(\bowtie) \cdot J$. Blanco $\cdot$ I. Conget $\cdot$ R. Gomis

Diabetes Unit, Hospital Clinic Universitari,

C/Villarroel 170,

08036 Barcelona, Spain

e-mail: esmatjes@clinic.ub.es

\section{Montaña $\cdot$ M. I. Real}

Interventional Angioradiology Unit,

Hospital Clinic Universitari,

Barcelona, Spain

R. Casamitjana

Biochemistry and Molecular Genetics Department,

Hospital Clinic Universitari,

Barcelona, Spain

M. Rovira

Bone Marrow Transplant Unit, Hospital Clinic Universitari,

Barcelona, Spain beta cells, as a facilitator of beta cell regeneration and as an immune modulator.

The infusion of autologous bone marrow was recently reported to restore insulin secretion in type 1 diabetes [6]. To reproduce these results, we evaluated the effect of an intrapancreatic infusion of autologous bone marrow blood on insulin production in patients with type 1 diabetes.

The present pilot study was designed to include ten patients with type 1 diabetes of more than 5 years duration and the following characteristics: inadequate glycaemic control $\left(\mathrm{HbA}_{1 \mathrm{c}}>8.5 \%\right.$ or recurrent hypoglycaemia) with intensified insulin treatment; free C-peptide $<0.033 \mathrm{nmol} / 1$ (basal and $6 \mathrm{~min}$ after administration of $1 \mathrm{mg}$ glucagon, as measured with GlucaGen, Novo Nordisk, Gentofte, Denmark). Patients gave informed consent and the study protocol

P. Marin

Hemotherapy Unit, Hospital Clinic Universitari, Barcelona, Spain

E. Esmatjes · I. Conget - R. Casamitjana $\cdot$ M. Rovira $\cdot$ R. Gomis P. Marin Institut d'Investigacions Biomèdiques August Pi i Sunyer (IDIBAPS),

Barcelona, Spain

E. Esmatjes $\cdot$ I. Conget $\cdot$ R. Casamitjana $\cdot$ R. Gomis CIBER de Diabetes y Enfermedades Metabólicas Asociadas (CIBERdem),

Barcelona, Spain

URL: www.ciberdem.org 
was approved by the Research Ethics Committee of the Hospital Clinic of Barcelona.

After 3 days of treatment with 5 to $10 \mu \mathrm{g} \mathrm{kg}^{-1} \mathrm{day}^{-1}$ of granulocyte colony-stimulating factor subcutaneously administered every $12 \mathrm{~h}, 70$ to $100 \mathrm{ml}$ of autologous bone marrow was obtained by multipuncture of the posterior superior iliac crest under general anaesthesia using heparin as anticoagulant. The material obtained was filtered and kept in heparin until infusion. The cells were stored overnight at $4^{\circ} \mathrm{C}$ in a Teflon bag (Life-cell; Baxter, Deerfield, IL, USA) and subjected the following morning to testing for lot-release criteria including sterility, viability, total nucleated and $\mathrm{CD} 34^{+}$(haemopoietic progenitor cells) cell content.

Once cells had passed the lot-release criteria, the material was infused the morning after it had been obtained. A selective arteriography of the coeliac trunk and the superior mesenteric artery through a transfemoral route (Simmons I 5F catheter; Terumo) was done. After obtaining a vascular map of the pancreatic area, superselective catheterisation of the most accessible pancreatic artery was performed (3.2 Progreat microcatheter; Terumo, Leuven, Belgium) to infuse the bone marrow.

After the procedure, the patients were observed for $24 \mathrm{~h}$ for possible procedure-related complications. The follow-up consisted of clinical visits every week during the 1 st month and monthly thereafter, and of telephone contact if necessary. At 1 week, and at 1, 3, 6 and 12 months, we planned to determine routine biochemistry, $\mathrm{HbA}_{1 \mathrm{c}}$, antiGAD antibodies and basal and glucagon-stimulated free C-peptide.

To date three patients have been treated, two of whom have been followed for 6 months. One patient died suddenly 3 months after treatment with the necropsy study showing myocardial infarction as the cause of death. Considering the time since the procedure, we do not believe that the infusion contributed to death. Unfortunately, we do not have information on pancreas status. The clinical characteristics of these three patients are detailed in Table 1.

The volume infused was 65 to $103 \mathrm{ml}$ with a quantity of CD $34^{+}$cells of $0.15 \times 10^{6}$ to $0.30 \times 10^{6}$ per $\mathrm{kg}$ body weight. The only adverse event reported was an auto-limited epigastric pain during bone marrow infusion in one patient (Table 1).

In the ten glucagon tests carried out during follow-up, C-peptide levels remained undetectable $(<0.033 \mathrm{nmol} / \mathrm{l})$, with no change in the insulin dose or metabolic control (Table 2), strongly suggesting that the treatment was ineffective in regenerating beta cell function. The Research Ethics Committee accordingly recommended suspending the trial and we decided to stop the study.

This study suggests that intrapancreatic autologous bone marrow infusion has no effect on insulin secretion in patients with type 1 diabetes. We decided to use total bone
Table 1 Baseline clinical characteristics and details of the procedure

\begin{tabular}{llll}
\hline Characteristic & Patient & & \\
\cline { 2 - 4 } & 1 & 2 & 3 \\
\hline Age (years) & 57 & 41 & 56 \\
Sex & Male & Male & Male \\
Duration of diabetes (years) & 30 & 5 & 14 \\
Weight $(\mathrm{kg})$ & 65 & 58 & 92 \\
BMI (kg/m ${ }^{2}$ ) & 21.7 & 19.6 & 30.7 \\
Medical history & & & \\
Retinopathy & No & Background & Proliferative \\
Nephropathy & Microalbuminuria & None & Macroalbuminuria \\
Stroke & Yes & No & No \\
Ischaemic heart disease & No & No & No \\
Peripheral vasculopathy & No & No & No \\
Procedure & & & \\
Bone marrow infused (ml) & 65 & 103 & 101 \\
Total nuclear cells $/ \mathrm{kg}$ & $0.59 \times 10^{8}$ & $0.75 \times 10^{8}$ & $0.46 \times 10^{8}$ \\
CD34 $/$ kg body weight & $0.30 \times 10^{6}$ & $0.32 \times 10^{6}$ & $0.15 \times 10^{6}$ \\
Artery of injection & Pancreatico-duodenal & Pancreatic magna & Pancreatic dorsal \\
Procedure time (min) & 120 & and transverse & 90 \\
Adverse events & None & 210 & Abdominal pain \\
& & during infusion & \\
\hline
\end{tabular}


Table 2 Pretreatment and follow-up variables after autologous bone marrow infusion
${ }^{\text {a }}$ Treated with insulin pump;

${ }^{\mathrm{b}}$ fasting/stimulated; ${ }^{\mathrm{c}}$ anti-

GADab, anti-GAD antibodies;

d episodes per week

\begin{tabular}{|c|c|c|c|c|c|}
\hline Variable & Baseline & 1 week & 1 month & 3 months & 6 months \\
\hline \multicolumn{6}{|l|}{ Weight (kg) } \\
\hline Patient 1 & 65 & 66 & 68 & - & - \\
\hline Patient 2 & 58 & 58 & 57 & 58 & 57 \\
\hline Patient 3 & 92 & 94 & 96 & 95 & 96 \\
\hline \multicolumn{6}{|c|}{ Insulin dose (U/day) } \\
\hline Patient 1 & 24 & 24 & 25 & - & - \\
\hline Patient $2^{\mathrm{a}}$ & 31 & 34 & 29 & 49 & 48 \\
\hline Patient $3^{\mathrm{a}}$ & 81 & 83 & 83 & 83 & 82 \\
\hline \multicolumn{6}{|c|}{ C-peptide $(\mathrm{nmol} / \mathrm{l})^{\mathrm{b}}$} \\
\hline Patient 1 & $<0.033 /<0.033$ & $<0.033 /<0.033$ & $<0.033 /<0.033$ & - & - \\
\hline Patient 2 & $<0.033 /<0.033$ & $<0.033 /<0.033$ & $<0.033 /<0.033$ & $<0.033 /<0.033$ & $<0.033 /<0.033$ \\
\hline Patient 3 & $<0.033 /<0.033$ & $<0.033 /<0.033$ & $<0.033 /<0.033$ & $<0.033 /<0.033$ & $<0.033 /<0.033$ \\
\hline \multicolumn{6}{|c|}{ Anti-GADab $^{c}(\mathrm{U} / \mathrm{ml})$} \\
\hline Patient 1 & $<0.1$ & $<0.1$ & $<0.1$ & - & - \\
\hline Patient 2 & 48.6 & 41.0 & 79.0 & 30.0 & 28.2 \\
\hline Patient 3 & 3.5 & 3.0 & 3.8 & 4.1 & 4.0 \\
\hline \multicolumn{6}{|c|}{ Hypoglycaemia (n) ${ }^{\mathrm{d}}$} \\
\hline Patient 1 & 2 & 0 & 3 & - & - \\
\hline Patient 2 & 0 & 0 & 4 & 3 & 3 \\
\hline Patient 3 & 0 & 0 & 4 & 0 & 0 \\
\hline \multicolumn{6}{|l|}{ HbA1c (\%) } \\
\hline Patient 1 & 8.9 & 8.8 & 9.4 & - & - \\
\hline Patient 2 & 9.5 & 9.3 & 8.0 & 8.7 & 8.0 \\
\hline Patient 3 & 10.4 & 10.3 & 8.7 & 9.1 & 9.2 \\
\hline
\end{tabular}

marrow cells rather than $\mathrm{CD} 34^{+}$purified cells in order to reproduce the previous report exactly [6] and because of the current lack of information on the efficiency of these two options. Although we only studied three patients, we think that the evidence obtained over the 6 months of follow-up, with repeated glucagon tests in which all the basal and stimulated C-peptide levels were below the sensitivity threshold of the method, is sufficient to support this affirmation.

Type 1 diabetes is a potential candidate for stem cell therapy and diabetic patients are strongly motivated to explore any way that may restore them to a non-diabetic condition. In this context, some private centres are offering treatment with autologous bone marrow to cure diabetes $[7,8]$.

Up to now, two papers on this technique have been published. One, mentioned above, was in type 1 diabetes patients, and its results are completely discordant with ours [6]. In the other, more recent study in patients with type 2 diabetes, Bhansali et al. [9] observed a moderate improvement in C-peptide levels in seven of ten patients treated with intrapancreatic autologous bone marrow transplantation. However, in this study patients were under an intensified regime of visits that could explain the improve- ment in metabolic control and, secondarily, also that in beta cell capacity through an amelioration of glucotoxicity.

Based on our experience and on the inconsistency of the previous information, we believe that intrapancreatic autologous bone marrow transplantation does not induce any relevant effect on beta cell function in type 1 diabetes patients with undetectable C-peptide levels. Our data, obviously, cannot rule out the possibility that bone marrow transplantation could be effective in preserving or even restoring beta cell function in recently diagnosed type 1 diabetes patients. However, a recent report, in which autologous umbilical cord blood infusion failed to preserve C-peptide levels in young newly diagnosed children 1 year after infusion, does not support this hypothesis [10].

The potential of stem cell therapy is enormous, but its practical clinical application must be the consequence of robust scientific evidence. Diabetes is a heterogeneous disease and it is essential to define which kind of patients may benefit from receiving cell therapy. Taking this into account, the results of the present study, albeit based on only a few cases, with specific characteristics, provide additional information to patients considering this currently available treatment. 
Duality of interest The authors declare that there is no duality of interest associated with this manuscript.

\section{References}

1. Ianus A, Holz GG, Theise ND, Hussain MA (2003) In vivo derivation of glucose-competent pancreatic endocrine cells from bone marrow without evidence of cell fusion. J Clin Invest 111:843-850

2. Moriscot C, de Fraipont F, Richard MJ et al (2005) Human bone marrow mesenchymal stem cells can express insulin and key transcription factors of the endocrine pancreas developmental pathway upon genetic and/or microeviromental manipulation in vitro. Stem Cells 23:594-603

3. Sun Y, Chen L, Hou XG et al (2007) Differentation of bone marrowderived mesenchymal stem cells from diabetic patients into insulinproducing cells in vitro. Chin Med J (Engl) 120:771-776
4. Tang DQ, Cao LZ, Burkhardt BR et al (2004) In vivo and in vitro characterization of insulin-producing cells obtained from murine bone marrow. Diabetes 53:1721-1723

5. Lechner A, Yang YG, Blacken RA, Wang L, Nolan AL, Habener JF (2004) No evidence for significant transdifferentiation of bone marrow into pancreatic $\beta$-cells in vivo. Diabetes 53:616-623

6. Mesples AD, Pretiñe B, Bellomo R (2007) Tratamiento de la diabetes mellitus tipo 1 con implante pancreático de células madre autologas. Endocrinol Nutr 54:512-518

7. Cell-Center at the Institute for Regenerative Medicine (2009) Available from www.xcell-center.com, accessed 24 December 2009

8. Fundación Don Roberto Fernandez Viña (2009) Available from www.fundacionfernandezvina.org, accessed 24 December 2009

9. Bhansali A, Upreti V, Khandelwal N et al (2009) Efficacy of autologous bone marrow derived stem cell transplantation in patients with type 2 diabetes mellitus. Stem Cells Dev 18:1407-1416

10. Haller M, Wasserfall C, Cintron M et al (2009) Autologous umbilical cord blood transfusion in very young children with type 1 diabetes. Diabetes Care 32:2041-2046 